Caring : Jurnal Keperawatan

Vol.8, No. 1, Maret 2019, pp. $15-22$

ISSN 1978-5755 (Online)

DOI: 10.29238

Journal homepage: http://e-journal.poltekkesjogja.ac.id/index.php/caring/

\title{
Pengaruh hidroterapi rendam kaki air hangat terhadap kekuatan otot pada pasien stroke non hemoragik
}

\section{The effect of hydrotherapy soak the air feet on muscle strength in non-hemorrhagic stroke patients}

\author{
Setiyawan ${ }^{1 a^{*}}$, Lina Pratiwi ${ }^{1}$, Noerma Shovie Rizqiea ${ }^{1}$ \\ ${ }^{1}$ Prodi Sarjana Keperawatan, STIKes Kusuma Husada Surakarta, Jl. Jaya Wijaya No. 11 \\ Kadipiro, Banjarsari, Surakarta, 57136, Indonesia \\ a stikes_kh@yahoo.com
}

\section{ARTICLE INFO}

\begin{tabular}{l} 
Article history \\
Received date \\
Revised date \\
Accepted date \\
\hline
\end{tabular}

\section{Keywords:}

Hydrotherapy

Muscular strength

Non-hemorrhagic stroke

Kata kunci:

Hidroterapi

Kekuatan otot

Stroke non hemoragik
A B S T R A C T / A B S T R A K

Non-hemorrhagic stroke is a disease which is related to a functional disorder of the brain due to the blood vessel blockage by a blood clot, or by the narrowing of an artery or some arteries that lead to the brain which causes weakness of muscular strength. One of the non-pharmacological therapies, which are beneficial to non-hemorrhagic stroke patients, is hydrotherapy. Hydrotherapy is a therapy which utilizes water to cure or relieve various complaints. One of which is the complaint of how to strengthen muscular strength. The objective of this research is to investigate the effect of warm footbath hydrotherapy to increase the muscular strength of non-hemorrhagic stroke patients. This research used the quasi-experimental research method ith pre-test and post-test nonequivalent control group design. Non-probability sampling with purposive sampling was used to determine its samples. The samples consisted of 40 respondents, into two groups: intervention and control group. The data of the research were analyzed by using the Wilcoxon's Test and Mann Whitney's Test. The result of the research shows that the footbath hydrotherapy had an effect on the muscular strength of the non-hemorrhagic stroke patients as indicated by the $p$-value $=0.000$, and there was a difference between the control group and the intervention group where the $p$-value was 0 . 008. The footbath hydrotherapy affected the muscular strength of non-hemorrhagic stroke patients. Thus, nurses as health practitioners are expected to administer warm footbath hydrotherapy to increase the muscular strength of nonhemorrhagic stroke patients. 
Stroke non hemoragik merupakan penyakit gangguan fungsional otak akibat sumbatan oleh bekuan darah, atau penyempitan sebuah arteri atau beberapa arteri yang mengarah ke otak yang menyebabkan kelemahan kekuatan otot. Terapi non farmakologi yang memiliki manfaat bagi penderita stroke non hemoragik salah satunya adalah hidroterapi. Hidroterapi adalah penggunaan air untuk menyembuhkan dan meringankan berbagai keluhan seperti untuk meningkatkan kekuatan otot. Penelitian ini bertujuan untuk mengetahui pengaruh hidroterapi rendam kaki air hangat terhadap kekuatan otot ekstermitas atas pada pasien stroke non hemoragik. Pada penelitian ini menggunakan desain penelitian quasi experiment dengan pendekatan pre test and post test nonequivalent control group. Sampel menggunakan tehnik non probability sampling dengan pendekatan purposive sampling. Jumlah sempel 40 responden. Analisis data dengan menggunakan uji Wilcoxon dan Mann Whitney. Hasil penelitian menunjukan ada pengaruh rendam kaki air hangat terhadap kekuatan otot pasien stroke non hemoragik dengan nilai $p$-value 0,000 dan ada perbedaan antara kelompok kontrol dan kelompok intervensi pasien stroke non hemoragik dengan nilai $p$-value 0,008. Terdapat pengaruh hidroterapi rendam kaki air hangat terhadap kekuatan otot ekstermitas atas pasien stroke non hemoragik. Perawat sebagai praktisi kesehatan diharapkan dapat memberikan hidroterapi rendam kaki air hangat untuk meningkatkan kekuatan otot pada pasien stroke non hemoragik.

Copyright (C) 2019 Caring : Jurnal Keperawatan. All rights reserved

\section{${ }^{\star}$ Corresponding Author:}

Setiyawan,

Prodi Sarjana Keperawatan, STIKes Kusuma Husada Surakarta

J. Jaya Wijaya No. 11 Kadipiro, Banjarsari, Surakarta, 57136, Indonesia

\section{PENDAHULUAN}

Stroke non hemoragik didefinisikan suatu sumbatan oleh bekuan darah, penyempitan sebuah arteri atau beberapa arteri yang mengarah ke otak, atau embolus (kotoran) yang terlepas dari jantung atau arteri ekstrakranial (arteri yang berada di luar tengkorak) yang menyebabkan sumbatan di satu atau beberapa arteri intrakranial (arteri yang berada di dalam tengkorak) (Irfan, 2010).

Hasil Riskesdas tahun 2013, prevalensi penyakit stroke di Indonesia meningkat seiring bertambahnya umur. Kasus stroke tertinggi yang terdiagnosis tenaga kesehatan adalah usia 75 tahun keatas $(43,1 \%)$ dan terendah pada kelompok usia 15-24 tahun yaitu sebesar (0,2\%). Prevalensi stroke berdasarkan jenis kelamin lebih banyak laki-laki $(7,1 \%)$ dibandingkan dengan perempuan $(6,8 \%)$. 
Masalah yang sering dialami oleh penderita stroke dan yang paling ditakuti adalah gangguan gerak. Kekuatan otot sangat berhubungan dengan sistem neuromuskuler yaitu seberapa besar kemampuan sistem saraf mengaktifasi otot untuk melakukan kontraksi. Sehingga semakin banyak serabut otot yang teraktifasi. Maka semakin besar pula kekuatan yang dihasilkan otot tersebut (Irfan, 2010). Kekuatan otot umumnya diperlukan dalam melakukan aktivitas. Sebagian besar pasien stroke non hemoragik membutuhkan kekuatan otot untuk mempertahakan keseimbangan tubuh, mengkordinasikan gerakan tubuh dan pemenuhan kebutuhan dasar seperti: berpakaian, makan, toileting, berjalan dan lainnya (Yulfa, 2013).

Rehabilitasi yang selama ini dilakukan pada pasien stroke untuk mengatasi kelumpuhan adalah dengan ROM. Efek ROM menghasilkan energi untuk kontraksi dan meningkatkan tonus otot polos ekstermitas, untuk membantu mengefektifkan atau mengoptimalkan mekanisme ROM perlu adanya terapi untuk memperbaiki dan meningkatkan sirkulasi sehingga dapat membantu menghantarkan energi keseluruh otot (Yulfa, 2013).

Air hangat adalah satu media terapi yang bisa digunakan untuk pengobatan, efek hidrostatik, hidrodinamik dan suhu hangatnya yang membuat peredaran darah di dalam tubuh menjadi lancar. Selain dapat memperlancar peredaran darah, air hangat juga memberikan efek ketenangan bagi tubuh (Kusumastuti, 2008 dalam Yulfa, 2013). Salah satu media yang menggunakan air hangat untuk terapi adalah dengan Hidroterapi. Hidroterapi adalah metode pengobatan menggunakan air untuk mengobati atau meringankan berbagai keluhan (Yulfa, 2013). Hidroterapi rendam hangat ini sangat mudah dilakukan oleh semua orang, tidak membutuhkan biaya yang mahal, tidak memiliki efek samping yang berbahaya (Perry \& Potter, 2006 dalam Damayanti, 2014).

Penelitian Prasetyo (2009), terapi latihan di air seperti berenang banyak manfaat bagi penderita stroke yaitu: ketersediaan oksigen dalam tubuh menjadi lebih baik, sehingga meningkatkan daya kerja otot dan oksigenasi otak. Terapi latihan di air juga memperlancar sirkulasi darah dan meningkatkan penyerapan oksigen ke dalam jaringan saraf, membuat jaringan sendi menjadi lebih lentur, menurunkan rasa nyeri, memberikan efek relaksasi, dan meningkatkan kemampuan gerak anggota tubuh.

Hasil studi pendahuluan di RSUD dr. Soediran Mangun Sumarso Wonogiri, pasien dengan stroke non hemoragik pada tiga bulan terakhir mulai dari bulan Agustus sebanyak 45 pasien, September sebanyak 58 pasien dan pada bulan Oktober sebanyak 57 pasien. Hasil observasi pasien stroke rata-rata didapatkan kekuatan otot berada diskala 2 dan 3. Penelitian ini bertujuan untuk mengetahui pengaruh hidroterapi rendam kaki air hangat terhadap kekuatan otot ekstermitas atas pada pasien stroke non hemoragik di RSUD dr. Soediran Mangun Sumarso Wonogiri.

\section{BAHAN DAN METODOLOGI PENELITIAN}

Penelitian ini dilakukan di RSUD dr. Soediran Mangun Sumarso Wonogiri pada bulan Februari - Mei 2018. Jenis penelitian ini bersifat quasi experiment dengan pendekatan pre test and post test nonequivalent control group. Populasi pada penelitian ini pasien stroke non hemoragik yang mengalami hemiparesis di RSUD dr. Soediran Mangun Sumarso Wonogiri sebanyak 57 pasien. Teknik pengambilan sempel menggunakan tehnik non probability sampling dengan 
pendekatan purposive sampling. Jumlah sempel 40 responden yang memiliki kriteria inklusi dan ekslusi. Analisa data menggunakan Wilcoxon dan Mann Whitney

\section{HASIL DAN PEMBAHASAN}

Hasil penelitian berdasarkan karakteristik responden:

Tabel 1. Distribusi frekuensi responden menurut usia dan jenis kelamin $(n=40)$

\begin{tabular}{ccccc}
\hline \multirow{2}{*}{ Umur } & \multicolumn{2}{c}{ Kontrol } & \multicolumn{2}{c}{ Intervensi } \\
\cline { 2 - 5 } & $\mathbf{n}$ & $\%$ & $\mathbf{n}$ & $\%$ \\
\hline$<50$ tahun & 1 & 5 & 7 & 35 \\
$50-60$ tahun & 16 & 80 & 8 & 40 \\
$>60$ tahun & 3 & 15 & 5 & 25 \\
Total & 20 & 100 & 20 & 100 \\
\hline Jenis Kelamin & & & & \\
\hline Laki-laki & 11 & 55 & 11 & 55 \\
Perempuan & 9 & 45 & 9 & 45 \\
Total & 20 & 100 & 20 & 100 \\
\hline
\end{tabular}

Hasil penelitian menunjukan bahwa sebagaian besar responden berusia 50-60 tahun sebanyak 16 pasien (80\%) pada kelompok kontrol, dan pada kelompok intervensi sebanyak 8 pasien (40\%). Usia 50-60 tahun merupakan kelompok usia yang rentan terhadap penyakit hipertensi yang mengakibatkan stroke. Hal ini berkaitan dengan penurunan fungsi organ tubuh yaitu penurunan elastisitas pembuluh darah (Tarwoto et al, 2007). Potter \& Perry (2010) juga menjelaskan bahwa hal ini merupakan akibat perubahan vaskuler dan akumulasi plak sklerotik sepanjang dinding pembuluh darah sehingga menyebabkan kakunya dinding pembuluh darah secara menyeluruh dan mengakibatkan meningkatnya resiko terjadinya hipertensi yang merupakan faktor resiko terjadinya stroke.

Berdasarkan hasil penelitian dan teori tersebut peneliti menyimpulkan bahwa pada usia 50-60 tahun lebih beresiko menderita stroke karena pada usia 50-60 tahun pembuluh darah lebih kaku karena adanya plak. Pertambahan usia yang menyebabkan terjadinya perubahan fisiologis yang terjadi pada tubuh dan penurunan fungsi tubuh.

Berdasarkan hasil penelitian menurut jenis kelamin pasien kelompok kontrol dan kelompok intervensi sama yaitu laki-laki sebanyak 11 pasien (55\%). Andarwati (2012) menyatakan dalam penelitiannya ada 73,3\% pasien stroke yang berjenis kelamin laki-laki. Jenis kelamin laki-laki mudah terkena stroke, hal ini dikarenakan lebih tingginya angka kejadian faktor resiko stroke (misalnya merokok dan hipertensi) pada laki-laki (American Heart Association, 2010).

Stroke non hemoragik terjadi pada laki-laki karena pada laki-laki terdapat hormon testoteron, dimana hormon ini dapat meningkatkan kadar LDL, apabila LDL tinggi maka dapat meningkatkan kadar kolesterol dalam darah yang merupakan faktor resiko terjadinya penyakit degeneratif seperti stroke (Watila dkk, 2010 dalam Prok, 2015).

Berdasarkan hasil penelitan dan teori tersebut peneliti menyimpulkan bahwa jenis kelamin laki-laki lebih beresiko terkena stroke hal ini dikarenakan lakilaki lebih banyak memiliki kebiasaan merokok, minum kopi dan konsumsi alkohol ini merupakan faktor resiko yang cukup berperan dalam penyakit stroke.

Hasil penelitian berdasarkan kekuatan otot adalah sebagai berikut: 
Hasil penelitian pre test kelompok kontrol kekuatan otot paling banyak mengalami kekuatan otot gerak penuh tanpa gravitasi sebanyak $45 \%$ sedangkan kelompok intervensi sebagaian besar mengalami kelemahan otot gerakan penuh dengan gravitasi sebanyak $60 \%$ (Tabel 2.).

Stroke dapat menyebabkan berkurangnya kekuatan otot disemua kelompok otot semua bagian tubuh. Otot-otot muka, tangan, lengan, kaki, dan tungkai pada sisi tubuh lebih sering terkena (hemiparesis). Kelumpuhan dan kelemahan sisi tubuh bagian kanan biasanya disebabkan karena kegagalan fungsi otak kiri, baik karena stroke sumbatan atau stroke perdarahan. Sebaliknya, jika terjadi kegagalan fungsi otak kanan, maka bagian sisi tubuh kiri akan menderita kelumpuhan (Suharjo, 2008).

Hasil penelitian berdasarkan kekuatan otot post test kelompok kontrol kekuatan otot meningkat menjadi gerakan penuh dengan gravitasi sebanyak $35 \%$ sedangkan pada kelompok intervensi kekuatan otot setelah diberikan hidroterapi rendam kaki air hangat pada ekstermitas atas sebagian besar kekuatan otot meningkat menjadi gerakan penuh, melawan gravitasi, terdapat sedikit tahanan sebanyak $50 \%$.

Latihan gerak secara intensif dibutuhkan oleh pasien setelah mengalami stroke non hemorgsik, untuk memaksimalkan pemulihan fungsi gerak yang hilang. Penanganan latihan gerak pasien stroke non hemoragik adalah kebutuhan yang mutlak bagi pasien untuk dapat meningkatkan kemampuan gerak dan fungsinya. Berbagai metode intervensi latihan seperti pemanfaatan Activity Daily Living (ADL), exercise therapy dan hydrotherapy telah terbukti memberikan manfaat yang besar dalam mengembalikan gerak dan fungsi pada pasien stroke (Pramudiarja, 2010 dalam Dinanti 2015).

Hidroterapi (hydrotherapy), yang sebelumnya dikenal sebagai hidropati (hydropathy), adalah metode pengobatan menggunakan air untuk mengobati atau meringankan kondisi yang menyakitkan dan merupakan metode terapi dengan pendekatan "lowtech" yang mengandalkan pada respon-respon tubuh terhadap air. Beberapa keuntungan yang diperoleh dari terapi air antara lain: untuk mencegah flu/demam, memperbaiki fertilitas, menyembuhkan kelelahan, meningkatkan fungsi imunitas, meningkatkan energi tubuh, dan membantu kelancaran sirkulasi darah (Chaiton, 2002 dalam Damayanti 2014).

Rendam kaki dengan air hangat setiap hari untuk meningkatkan sirkulasi darah. Terapi rendam kaki dengan air hangat mencapai serangkaian perawatan kesehatan yang efisien melalui tindakan pemanasan, tindakan mekanis dan tindakan kimia air (Asia Traditional Chineses Medicine, 2013 dalam Solechah dkk, 2017). 
Tabel 2. Distribusi frekuensi responden berdasarkan kekuatan otot pre test dan post test $(\mathrm{n}=40)$

\begin{tabular}{|c|c|c|c|c|c|c|c|c|}
\hline \multirow{3}{*}{ Kekuatan otot } & \multicolumn{4}{|c|}{ pre test } & \multicolumn{4}{|c|}{ post test } \\
\hline & \multicolumn{2}{|c|}{$\begin{array}{l}\text { kelompok } \\
\text { kontrol }\end{array}$} & \multicolumn{2}{|c|}{$\begin{array}{l}\text { kelompok } \\
\text { intervensi }\end{array}$} & \multicolumn{2}{|c|}{$\begin{array}{l}\text { kelompok } \\
\text { kontrol }\end{array}$} & \multicolumn{2}{|c|}{$\begin{array}{l}\text { kelompok } \\
\text { intervensi }\end{array}$} \\
\hline & $\mathbf{n}$ & $\%$ & $\mathbf{n}$ & $\%$ & $\mathbf{n}$ & $\%$ & $\mathbf{n}$ & $\%$ \\
\hline Tidak ada kontraktilitas & 1 & 5 & 0 & 0 & 1 & 5 & 0 & 0 \\
\hline Kontraktilitas ringan, tidak ada gerakan & 3 & 15 & 0 & 0 & 3 & 15 & 0 & 0 \\
\hline Gerakan penuh tanpa gravitasi & 9 & 45 & 8 & 40 & 5 & 25 & 2 & 10 \\
\hline Gerakan penuh dengan gravitasi & 7 & 35 & 12 & 60 & 7 & 35 & 8 & 40 \\
\hline $\begin{array}{c}\text { Gerakan penuh, melawan gravitasi, } \\
\text { terdapat sedikit tahanan }\end{array}$ & 0 & 0 & 0 & 0 & 4 & 20 & 10 & 50 \\
\hline $\begin{array}{c}\text { Gerakan penuh, melawan gravitasi, } \\
\text { tahanan penuh }\end{array}$ & 0 & 0 & 0 & 0 & 0 & 0 & 0 & 0 \\
\hline Total & 20 & 100 & 20 & 100 & 20 & 100 & 20 & 100 \\
\hline
\end{tabular}

Hasil penelitian dari pengaruh hidroterapi rendam kaki air hangat terhadap kekuatan otot pasien stroke non hemoragik adalah sebagai berikut:

Tabel 3. Hasil uji pengaruh hidroterapi rendam kaki air hangat terhadap kekuatan otot pasien stroke non hemoragik.

\begin{tabular}{ccccc}
\hline \multirow{2}{*}{ Kelompok } & \multicolumn{2}{c}{ Rata-rata } & Selisih & $\boldsymbol{p}$ \\
\cline { 2 - 5 } & Pre test & Post test & & 0,005 \\
Kontrol & 2,10 & 2,50 & 0,40 & 0,000 \\
Intervensi & 2,60 & 3,40 & 0,80 & \\
\hline
\end{tabular}

Hasil analisis uji wilcoxon menunjukan ada peningkatan kekuatan otot ekstermitas atas pada kelompok kontrol setelah dilakukan ROM dimana nilai $p$ value $0,005<0,05$. Pada kelompok intervensi setelah dilakukan Hidroterapi rendam kaki air hangat pada ekstermitas atas dimana nilai $p$-value 0,000 0,05 artinya ada pengaruh Hidroterapi rendam kaki air hangat terhadap kekuatan otot pada ekstermitas atas pasien stroke non hemoragik. Santos et,al (2011) membuktikan dalam penelitiannya bahwa ada 10 pasien dengan stroke mengalami peningkatan dalam kinerja mobilitas fungsional mereka selama 12 sesi hidroterapi.

Melakukan Hidroterapi rendam kaki air hangat memberikan perpindahan panas dari air hangat kedalam tubuh melalui telapak kaki. Kerja air hangat pada dasarnya adalah meningkatkan sirkulasi (sel) dengan melakukan pengaliran energi melalui konveksi (pengairan melalui medium cair) sehingga terjadi pelebaran pembuluh darah ke seluruh tubuh yang berdampak pada peningkatkan kekuatan otot (Lalage 2015, dalam Dilianti, 2017)

Stimulasi yang diberikan Hidroterapi rendam kaki air hangat akan menyebabkan sel mengalami vasodilatasi yang akan mengakibatkan aliran darah lancar dan membawa nutrisi dan oksigen lebih banyak ke sel-sel otak dan otot mendapatkan nutrisi yang cukup termasuk zat kalsium dan kalium. Peningkatan ion kalsium dalam sitosol terjadi akibat pelepasan ion yang semakin banyak dari reticulum sarkoplasmik, ion kalium didalam otot berfungsi untuk melakukan potensi aksi otot sehingga masa otot dapat dipertahankan dan kerja otot dapat meningkat. Akibat aliran darah yang lancar dapat meningkatkan suplai oksigen ke sel-sel otot.

Oksigen harus disuplai darah ke otot untuk memproduksi ATP didalam mitokondria otot. Mitokondria berperan dalam proses pembuatan ATP yang diperlukan otot untuk berkontraksi. Kontraksi otot diawali dengan pengeluaran 
asetilkolin yang menyebabkan potensi aksi atau rangsangan merambat keseluruh permukaan membran otot. Hal ini menyebabkan ion-ion kalsium lepas dalam jumlah besar ke dalam sarkoplasma sehingga masa otot dapat dipertahankan, kerja otot dapat meningkat akibatnya kekuatan otot ekstermitas atas meningkat (Guyton \& Hall, 2006 dalam Sukawana dkk, 2013).

Berdasarkan hasil penelitian dan teori tersebut peneliti menyimpulkan bahwa hidroterapi rendam kaki air hangat dapat menyebabkan pelebaran pembuluh darah ke seluruh tubuh termasuk pada pada bagian ekstermitas atas. Akibat aliran darah yang lancar dapat meningkatkan suplai oksigen ke sel-sel otot.

Hasil uji beda mean kelompok kontrol dan kelompok intervensi adalah sebagai berikut:

Tabel 4. Hasil uji perbedaan kelompok kontrol dan kelompok intervensi

\begin{tabular}{cccc}
\hline Kelompok & Nilai selisih & $\boldsymbol{p}$ & Keputusan \\
\hline Kontrol & 0,40 & \multirow{2}{*}{0.008} & H0 ditolak \\
\hline Intervensi & 0,80 & & \\
\hline
\end{tabular}

Hasil analisis uji beda pengaruh dengan Mann Whitney diperoleh nilai $p=$ 0,008 artinya ada perbedaan antara kelompok kontrol dan kelompok intervensi pada ekstermitas atas. Stimulasi yang diberikan Hidroterapi rendam kaki air hangat akan menyebabkan sel mengalami vasodilatasi yang akan mengakibatkan aliran darah lancar dan membawa nutrisi dan oksigen lebih banyak ke sel-sel otak dan otot mendapatkan nutrisi yang cukup termasuk zat kalsium dan kalium. Peningkatan ion kalsium dalam sitosol terjadi akibat pelepasan ion yang semakin banyak dari reticulum sarkoplasmik, ion kalium didalam otot berfungsi untuk melakukan potensi aksi otot sehingga masa otot dapat dipertahankan dan kerja otot dapat meningkat. Akibat aliran darah yang lancar dapat meningkatkan suplai oksigen ke sel-sel otot.

Oksigen harus disuplai darah ke otot untuk memproduksi ATP didalam mitokondria otot. Mitokondria berperan dalam proses pembuatan ATP yang diperlukan otot untuk berkontraksi. Kontraksi otot diawali dengan pengeluaran asetilkolin yang menyebabkan potensi aksi atau rangsangan merambat keseluruh permukaan membran otot. Hal ini menyebabkan ion-ion kalsium lepas dalam jumlah besar ke dalam sarkoplasma sehingga masa otot dapat dipertahankan, kerja otot dapat meningkat akibatnya kekuatan otot ekstermitas atas meningkat (Guyton \& Hall, 2006 dalam Sukawana dkk, 2013).

Hidroterapi rendam kaki air hangat dapat memperbaiki sirkulasi darah sehingga dapat membantuk menghantarkan energi keseluruh otot dan untuk membantu mengoptimalkan peningkatan kontraksi dan peningkatan tonus otot polos ekstermitas perlu adanya latihan gerak ROM. Latihan ROM dapar menimbulkan rangsangan sehingga meningkatkan aktivitas dari kimiawi neuromuskular dan muskuler. Rangsangan melalui neuromukular akan meningkatkan rangsangan pada serat saraf ekstermitas terutama saraf parasimpatis yang merangsang untuk produksi asetilcolin, sehingga mengakibatkan kontraksi. Mekanisme melalui muskus terutama otot polos ekstermitas akan meningkatkan metabolism pada metakondria untuk menghasilkan ATP yang dimanfaatkan oleh otot ekstermitas sebagai energi untuk kontraksi dan meningkatkan otot polos ekstermitas (Sanches, et al, 2006 dalam Rahayu 2015). 
Responden yang mengalami peningkatan kekuatan otot sesudah dilakukan Hidroterapi rendam kaki air hangat disebabkan responden dengan teratur melakukan Hidroterapi rendam kaki air hangat selama 20 menit selama 3 kali, responden juga sering menggerak-gerakan ekstermitas yang mengalami kelemahan dengan cara dibantu ekstermitas yang sehat.

\section{KESIMPULAN}

Hasil penelitian menunjukan ada pengaruh Hidroterapi rendam kaki air hangat terhadap kekuatan otot pasien stroke non hemoragik dengan nilai $p$-value 0,000 dan ada perbedaan antara kelompok kontrol dengan kelompok intervensi kekuatan otot pasien stroke non hemoragik dengan nilai $p$-value 0,008 . Hasil penelitian ini diharapkan dapat mengembangkan penelitian lebih lanjut mengenai hidroterapi rendam kaki air hangat yang memiliki banyak manfaat seperti untuk mengatasi nyeri rematik dan insomnia.

\section{DAFTAR PUSTAKA}

Andarawati, N.A., (2013). Pengaruh latihan ROM terhadap peningkatan kekuatan otot pasien hemiparese post stroke di RSUD Dr. Moewardi Surakarta

Damayanti, D., Aniroh, U\& Priyanto., (2014). Perbedaan tekanan darah sebelum dan sesudah dilakukan hidroterapi rendam hangat rendam hangat pada penderita hipertensi. Jurnal kesehatan Ngudi Waluyo Ungaran.

Dinanti, Elisa Ling,. dkk (2015), Pengaruh Range Of Motion (Rom) Pasif Terhadap Peningkatan Sudut Rentang Gerak Ekstremitas Atas Pasien Stroke Di RSUD Tugurejo Semarang

Dilianti, I, C \& Candrawati, E,. (2017). Evektivitas hidroterapi terhadap penurunan tekanan darah pada lansia penderita hipertensi dipanti wreda Al-Isilah malang.

Irfan, M., (2010). Fisioterapi Bagi Insan Stroke. Yogyakarta : Graha ilmu.

Potter, P.A., \& Perry, A.G. (2010). Fundamental Keperawatan (Edisi 7) (Buku 2) (Adrina Ferderia, Nggie \& Marina Albar, Penerjemah). Jakarta: Salemba Medika.

Prasetyo, Y., (2009). Terapi latihan di air bagi penderita stroke. Jurnal medikora. Volume 5, Nomer 2, halaman 163-172.

Rahayu, Nur, Ika, Kun,. (2015). Pengaruh pemberian latihan range of motion (rom) terhadap kemampuan motorik pada pasien post stroke di rsud gambiran. Jurnal Keperawatan.

Riset Kesehatan Dasar (Riskesdas). (2013).Badan Penelitian dan Pengembangan Kesehatan Kementerian RI tahun 2013.Diakses: 15 Oktober 2017, dari http://www.depkes.go.id/resources/download/general/Hasil\%20Riskesdas\%20203.pdf

Santos et al,. (2011). Evaluation of Functional mobility of patients with stroke sequel after treatmen in hydrotherapypool using the timed up on go test.

Solechah \& Nurul,. (2017). Pengaruh terapi rendam kaki dengan air hangat terhadap penurunan tekanan darah pada pasien dengan hipertensi di puskesmas bahu manado. Ejurnal keperawatan, volume 5, nomer 1.

Suharjo,. (2008). Gaya hidup dan penyakit modern. Yogyakarta: Konisius

Sukawana, I, W,. Sukarjo I, M \& Diputra, I, K, W,. (2013). Akupuntur scapula terhadap kekuatan otot ekstermitas atas pasien stroke non hemoragik.

Tarwoto., Wartonah., \& Suryati. (2007). Keperawatan medikal bedah gangguan sistem persarafan. Jakarta: sagung seto.

Yulfa, N, R., (2013). Perbedaan tingkat kekuatan otot pasien stroke yang diberikan ROM dengan terapi oukup di RSUD Ambarawa 